\title{
Why Do Some Countries Develop and Others Not?
}

\author{
Ian Goldin
}

\section{Introduction}

How individuals and societies develop over time is a key question for global citizens. Too many people in the world still live in extreme poverty. About one billion people live on less than $\$ 1.25$ a day (the World Bank's definition of extreme or absolute poverty) while about 2.2 billion people live on less than $\$ 2$ per day. What can be done about this?

Development Studies as an academic discipline is relatively new, but the questions being asked are not-philosophers have puzzled over them for millennia. There are many definitions of development and the concept itself has evolved rapidly over recent decades. To develop is to grow, which many economists and policymakers have taken to mean economic growth. Yet development is not confined to economic growth. Development is no longer the preserve of economists and the subject itself has enjoyed rapid evolution to become the subject of interdisciplinary scholarship drawing on politics, sociology, psychology, history, geography, anthropology, medicine and many other disciplines.

This chapter draws extensively on Ian Goldin, The Pursuit of Development: Economic Growth, Social Change and Ideas, Oxford University Press, 2017. Readers are referred to the book for the full references and for recommendations and further reading.

\footnotetext{
I. Goldin ( $\triangle)$

Oxford Martin School, University of Oxford, Oxford, UK

e-mail: ian.goldin@oxfordmartin.ox.ac.uk
} 


\section{Why Do Some Countries Develop and Others Not?}

A hundred years ago, Argentina was amongst the seven wealthiest nations in the world, but now ranks 43rd in terms of real per capita income. In 1950, Ghana's per capita income was higher than that of South Korea; now South Korean people are more than 11 times wealthier than the citizens of Ghana. Meanwhile, more than 20 failed states and over a billion people have seen little progress in development in recent decades, whilst over three billion people have seen remarkable improvements in health, education and incomes.

Within countries, the contrast is even greater than between countries. Extraordinary achievements enjoyed by some occur alongside both the absolute and relative deprivation of others. What is true for advanced societies, such as the United Kingdom and United States, is even more so in most, but not all, developing countries.

Many factors accounting for the successes and failures in the extreme unevenness of development outcomes. There is an extensive literature which seeks to explain outcomes on the basis of natural resource endowments, geography, history, cultural or other.

Overall, the evidence points to divergence-rather than convergence-in recent decades, although there is some variation amongst geographical sub-groupings, with a set of Southeast Asian economies (the "tigers") displaying evidence of convergence. In 1993 Parente and Prescott studied 102 countries over the period from 1960 to 1985 . They found that disparities in wealth between rich and poor countries persist, despite an average increase in incomes, although there is some evidence of dramatic divergence within Asia, which is consistent with some South East Asian economies-Japan, Taiwan, South Korea and Thailand-catching up with the West. $\mathrm{Li}$ and $\mathrm{Xu}$, have highlighted the extent to which the real incomes of seven South East Asian economies have grown 3.5 times (Malaysia) to 7.6 times (China) faster than the United States and the G10 economies for the period from 1970 to 2010.

The World Bank attributed the "East Asian Miracle" to sound macroeconomic policies with limited deficits and low debt, high rates of savings and investment, universal primary and secondary education, low taxation of agriculture, export promotion, promotion of selective industries, a technocratic civil service, and authoritative leaders. However, the Bank failed to highlight the extent to which the achievements came at the expense of civil liberties, and that far from being free markets the governments concerned subjugated the market (and suppressed organised labour), often with the generous support of the United States and other development and military aid programmes, following the Korean and Vietnam Wars.

Others have argued that South East Asia's relative success had more to do with pursuing strategic rather than "close" forms of integration with the world economy. In other words instead of opting for unbridled economic liberalisation in line with the Neo-Classical market friendly approach to development, countries such as 
Japan, South Korea and Taiwan selectively intervened in the economy in an effort to ensure that markets flourished. Several well-known commentators including Ajit Singh, Alice Amsden and Robert Wade have documented the full range of measures adopted by these countries, which appear to constitute a purposive and comprehensive industrial policy. These measures include the use of long-term credit (at negative real interest rates), the heavy subsidization and coercion of exports, the strict control of multinational investment and foreign equity ownership of industry (in the case of Korea), highly active technology policies, and the promotion of large scale conglomerates together with restrictions on the entry and exit of firms in key industrial sectors. The relative contribution of selective forms of intervention on the one hand, and market friendly liberalisation and export orientation on the other, to the success of the South East Asian economies remains a subject of debate.

\subsection{Poverty and Inequality}

Income measures are only one dimension of poverty. Other indicators, including those relating to infant and child mortality, illiteracy, infectious disease, malnutrition and schooling are also important. A number of countries have made extraordinary strides in overcoming poverty. In some, progress has been across the board, whereas others have managed to achieve very significant progress on one dimension but fallen back on others. With similar levels of average per capita incomes, in Bangladesh average life expectancy is 71, whereas in Zimbabwe it is 60 and in Tanzania it is 61 .

Inequality between countries and within countries requires an analysis which goes beyond the headline economic indicators. While average per capita incomes are growing in most countries, inequality is also growing almost everywhere. The world's richest $20 \%$ of people account for three quarters of global income and consume about $80 \%$ of global resources, while the world's poorest $20 \%$ consume well under $2 \%$ of global resources. Where poor people are is also changing. Twenty years ago over $90 \%$ of the poor lived in low income countries; today approximately three quarters of the world's estimated one billion people living on less than $\$ 1.25$ per day live in middle income countries.

\subsection{Explaining Different Development Trajectories}

Every country is unique. Yet it is still possible to identify a range of factors that affect development trajectories. A number of economic historians have shown that patterns of resource endowments can reinforce inequalities and favour elites, with this in turn leading to "capture" and predatory institutional development. The resource curse has been examined by Paul Collier (2007), Jeffrey Frankel, and 
others, who have shown that ample endowments of natural resources may be linked with stunted institutional development, particularly in the case of mining and oil. In mining and oil multinational or local investors have often operated behind a veil of secrecy. The awarding of contracts for extractive industries provides a source of power and patronage to corrupt leaders. Evidence of corruption by international firms who have made offshore payments through international banks provides a clear example of how both advanced and developing countries have a responsibility to clamp down on corrupt practices, not least in mitigating the risks associated with the extraction of natural resources.

For the classical and neo-classical economists, as well as their critics on the Left, natural and human resource endowments were a key determinant of trade and market integration. While the former group argued that revealed comparative advantage would lead to development, the critics argued the opposite, concluding that it would lead to more uneven development. Both groups saw international trade as a critical determinant of growth, explaining the convergence (or divergence) of growth rates and global incomes, with Dani Rodrik, Jeffrey Sachs and Andrew Warner, Jeffrey Frankel and David Romer, and David Dollar and Aart Kray contributing conflicting evidence of the relationship between trade and development.

Jared Diamond, Jeffrey Sachs and others explain development outcomes by providing geographical explanations. They argue that moderate advantages or disadvantages in geography can lead to big differences in long-term economic performance and that poor economic performance can be explained in terms of the "bad geography" theses. Geography is thought to affect growth in at least four ways. Firstly, economies with coastal regions, and easy access to sea trade, or nearby large markets have lower transport costs and are likely to outperform economies that are distant and landlocked. Secondly, tropical climatic zones face a higher incidence of infectious diseases, and malaria, bilharzia and other parasitic infections which hold back economic performance by reducing worker productivity. For example, in 2015, malaria caused an estimated 438,000 deaths mostly among sub-Saharan African children. In addition, a high incidence of disease can raise fertility rates and add to the demographic burden of a country. Thirdly, geography affects agricultural productivity in a variety of ways. Grains are less productive in tropical zones, with a hectare of land in the tropics yielding on average around one-third of the yield in temperate zones. Fragile soils in the tropics and extreme weather are part of the explanation, as is the higher incidence of pests and parasites which damage crops and livestock. Fourthly, as the tropical regions have lower incomes and crop values, agri-businesses invest less in tropical regions, and national research institutions are similarly poorer. The implication is that international agencies, such as the Consultative Group for International Agricultural Research (CGIAR) - which is donor funded-have a particular responsibility to raise the output of tropical agriculture. A similar point can be made with respect to tropical diseases, with low purchasing power holding back development of drugs to combat many of the most significant tropical diseases.

William Easterly and Ross Levine as well as Rodrik and others, have argued that the impact of geography is regulated through institutions and that good governance 
and institutions can provide the solution to bad geography. For example, good governments can build efficient roads and irrigation systems, and invest in vital infrastructure as well as enforce legal contracts and curb corruption. In short, good governance minimises uncertainty and transaction costs and can overcome bad geography. However, bad governance does not. For Easterly there are too many "Ifs, buts and exceptions" to Sachs' bad geography thesis. Destructive governments rather than destructive geography may also explain the poverty of nations.

Rodrik and others argue that it is the quality of institutions - property rights and the rule of law - that ultimately matters. Once the quality of institutions is taken into account (statistically "controlled for" using econometric techniques), the effect of geography on economic development fades away. However, as Rodrik notes, the policy implications associated with the "institutions rule" thesis are difficult to discern and likely to vary according to context. This in part is because institutions are partly endogenous and co-evolve with economic performance. As countries become better off they have the capacity to invest in more education and skills and better institutions, which in turn makes them better off.

For Daron Acemoglu, Smon Johnson and James Robinson, the development of institutions which facilitate or frustrate development, are rooted in colonialism and history. These authors argue that contemporary patterns of development are largely the result of different forms of colonialism and the manner in which particular countries were, or were not, settled over the past 500 years. The purposes and nature of colonial rule and settlement shaped institutions which have had lasting impacts. In countries with high levels of disease, high population density, and lots of resources, colonial powers typically set up "extractive states" with limited property rights and few checks against government power in order to transfer resources to colonizers, such as was the case in the Belgium Congo. In countries with low levels of disease and low population density, but also less easily extractable resources, settlement was more desirable and colonial powers attempted to replicate European institutions-strong property rights and checks on the abuse of power-and made an effort to develop agriculture and industry as was the case in Canada, United States, Australia and New Zealand. According to this thesis, the legacy of colonialism led to an institutional reversal that made poor countries rich, and rich countries poor.

Although we may well live in a world shaped by natural resource endowments, geography, history and institutions, politics and power can still play a decisive role in terms of driving economic performance and determining vulnerability to poverty. In Amartya Sen's Poverty and Famines, he showed that political power and rules that are embedded in ownership and exchange determine whether people are malnourished or have adequate food, and that malnourishment is not mainly the result of inadequate food supply. Sen shows how droughts in North Africa, India and China in the nineteenth and Twentieth centuries were catastrophic for social and political reasons, with power relations, not agricultural outcomes, leading to widespread starvation and destruction of the peasantry. In 1979, Colin Bundy, in The Rise and Fall of the South African Peasantry was among a new wave of historians who argued that colonialism led to the deliberate collapse of a previously thriving domestic 
economy. In 1997, Jared Diamond's, Blood, Germs and Steel, while emphasising the importance of geography and history, showed how technology, culture, disease and other factors led to the destruction of native American and other previously thriving communities. These authors, echoing Marx, highlighted the extent to which development can be a very bloody business, even if the longer term consequences may be to bludgeon societies into a new era.

If the abuse of power can set development back, what about the counter argument that democracy leads to more rapid and equitable development outcomes? According to Irma Adelman, the long-term factors governing the association between development and democracy include the growth of middle classes, increase in quantity and quality of education, urbanisation (including more infrastructures), the need for participation in development strategies, and the need to manage the psychological and social strains arising from change. Acemoglu, Robinson and others went further in 2014, arguing that democracy does cause growth, and that it has a significant and robust positive effect on GDP. Their results suggest that democracy increases future GDP by encouraging investment, increasing schooling, and inducing economic reforms, improving public good provision, and reducing social unrest. The difficulty of defining democracy, and the weight attached to the non-democracies which have enjoyed very rapid growth, such as China and Singapore, as well as the slowing of growth and paralysis in decision making in many parts of Latin America, Europe and other democratic regions means that the academic jury remains divided on the relationship between development and democracy.

\section{What Can Be Done to Accelerate Development?}

Peace and stability are essential for development as conflict and war leads to development in reverse, destroying not only lives, but also the infrastructure and cohesion which are fundamental to development. Literacy and education-and particularly the role of education for women-are vital, not least in overcoming gender inequities. The literature shows that these are key contributors to declining fertility and improved family nutrition and health. Infrastructure investments, particularly in clean water, sewerage and electricity, as well as rural roads, are essential for growth and investment, as they are for achieving improved health outcomes. The rule of law and the establishment of a level playing field, through competition and regulatory policies are vital for ensuring that the private sector is allowed to flourish. The capturing of the market by monopolies or small elites, often with the connivance of politicians or civil servants, is shown to lead to the skewing of development and growing inequality.

No country is an island economically and the way that countries engage with the rest of the world is a key determinant of their development outcomes. The increasing integration of the world, in terms of financial, trade, aid and other economic flows, as well as health, educational, scientific and other opportunities requires an increasingly sophisticated policy capability. So too does the management of the risks 
associated with increased integration into the global community. The threat posed by pandemics, cyberattacks, financial crises and climate change and other global developments could derail the best laid development efforts. Systemic risks have a particularly negative impact on development outcomes, and without exception tend to have negative distributional consequences. The existence of effective policies, or their absence, shapes the harvesting of the upside opportunities and mitigation of the risks.

\subsection{Literacy, Education and Health}

There are both theoretical and empirical reasons for believing that literacy and education are essential for economic and social development. The education of girls has served to reduce widespread gender inequalities and has improved the relative position of women in poor countries. The education and empowerment of women has been associated with improvements in a range of development outcomes, and is associated with sharp falls in infant mortality and fertility.

The links between education, health and development are many and varied; in many contexts "all good things" (or "bad things") go together. The demographic transition describes how fertility and mortality rates change over the course of economic and social development. In the early or first phase of development birth rates and mortality rates are high due to poor education, nutrition and healthcare. In such circumstances, characteristic of many developing countries prior to the Second World War, population growth remains low. As living standards, nutrition and public health improve during the second phase of the transition, mortality rates tend to decline. As birth rates remain high, population growth becomes increasingly rapid. Historically, much of Africa, Asia and Latin America experienced this trend during the second half of the twentieth century.

Over half the countries in the world, including many developing countries, have now entered the third stage of demographic transition. This is characterised by improvements in education and health along with changes in technology, including the widespread availability of contraceptives, which give women greater choice. In this stage, urbanisation and greater female participation in the workforce reduces the economic and social benefit of having children and raises the costs. In the fourth stage of the demographic transition, both mortality and birth rates decline to low or stable levels and population growth begins to fall. Many developed countries have passed this stage and face the prospect of zero or negative population growth. As this trend continues, countries experience a rapid decline in fertility, to below replacement level. The combination of rapidly falling fertility and continued increases in life expectancy leads to rapid increases in median ages, with these projected to double in all regions, except for Africa, in the period to 2050. 


\subsection{Gender and Development}

Gender inequalities and unequal power relations skew the development process. In many developing countries women's opportunities for gainful forms of employment are limited to subsistence farming - often without full land ownership rights or access to credit and technology that might alter production relations and female bargaining power. In many societies, women are confined either to secluded forms of home-based production that yield low returns, or to marginal jobs in the informal economy where income is exceptionally low and working conditions are poor. In addition women typically have to endure the "double burden" of employment and domestic work - the latter includes housework, preparing meals, fetching water and wood, and caring for children-amongst many other tasks.

A range of studies over the last four decades have shown that households do not automatically pool their resources, and that who earns and controls income can make a major difference to household well-being. Numerous empirical studies examining the relationship between women's market work, infant feeding practices and child nutrition indicate that the children of mothers with higher incomes are better nourished. In the gold mining industry in Africa for example an increase in women's wage earning opportunities has been shown to be associated with the removal of healthcare barriers, the halving of infant mortality rates—especially for girls—and a reduction in the acceptance rate of domestic violence by $24 \%$.

The distribution of benefits and burdens becomes more equitable when women have a stronger voice and more access to education and employment. Improving women's economic opportunities can prove a highly effective way to reduce poverty and improve women's relative position and that of their children. Ensuring that more women are enrolled in education, can read, write and count, and have appropriate skills for jobs are also likely to improve the overall well-being of households. Steps to tackle restrictive cultural norms and laws regarding women's education, participation in the labour force, ownership of land and other assets, inheritance rights, marriage and freedom to participate in society make important contributions in this regard.

Many of these initiatives are likely to translate into specific sectoral priorities and policies-for example vocational training, access to cheap transport, and access to saving and credit markets. Women are disadvantaged in the credit market as they typically have no collateral. Innovative microfinance schemes have sought to overcome this by providing flexible loans on favourable terms, often requiring no collateral or with zero interest, for investment in small scale productive activities-such as rearing chickens or a goat. The most well-known example is the Grameen Bank, which has been providing finance to poor Bangladeshis since the late 1970s. By 2015 cumulative disbursement of loans exceeded $\$ 16$ billion and the bank had provided loans to over seven million individuals, $97 \%$ of whom are women.

The participation of women in the workplace together with gender differences in pay, promotion and business leadership are important aspects of empowerment. 
Political representation and gender disparities in healthcare and education (often reflecting "boy preference" in many parts of the world) are also key indicators of social progress. Since the introduction of the MDGs in 1990, women in many countries have made progress towards parity with men, although much more still needs to be done. Significant progress has been made in terms of tackling female infant mortality and enabling your girls to attend school, although gross disparities between men and woman persist across the board. Despite some notable progress, so too do practices which fundamentally constrain women, such as female genital mutilation, which affects at least 125 million women in over 29 countries.

Less progress has been made in terms of women's employment in the labour market - especially in Asia where ground has actually been lost over the last 25 years. This may have far reaching implications beyond our concern with fairness and gender justice. A recent speculative study suggests that advancing gender equality in the workplace could add as much as \$12 trillion to global GDP by 2025 (assuming every country in the world could match the performance of its fastest improving neighbour in terms of progress towards gender equality). While the advanced economies have the most to gain, developing countries and regions could expect to benefit from significant increases in income by 2025 including India ( $\$ 0.7$ trillion or $11 \%$ of GDP), Latin America (\$1.1 trillion or 14\% of GDP), China ( $\$ 2.5$ trillion or $12 \%$ of GDP), sub-Saharan Africa ( $\$ 0.3$ trillion or $12 \%$ of GDP), and the Middle East and North Africa (\$0.6 trillion or 11\% of GDP) (amongst other countries and regions).

Knowing that education, health and nutrition, and gender equity—amongst other things - are important for development is only the start. Developing policies to tackle these issues is a major challenge. In many countries, for example, the failure of education systems relate to a lack of quality rather than quantity of resources spent. In India case studies have catalogued a number of issues including poorly trained and qualified teachers, mindless and repetitive learning experiences, lack of books and learning material, poor accountability of teachers and unions, school days without formal activities, and high rates of absenteeism amongst staff and students. Moreover, improving outcomes is more complex than finding money for school fees or budgets for teachers. Issues such as having appropriate clothes for the walk to school or the availability of single sex toilets at school can play a decisive role, especially for girls.

\subsection{Agriculture and Food}

Agriculture provides the main source of income and employment for the $70 \%$ of the world's poor that live in rural areas. The price and availability of food and agricultural products also dramatically shapes the nutrition and potential to purchase staples for the urban poor.

Policies which discriminate against farmers and seek to create cheap urban food by holding down agricultural prices can perversely lead to rising poverty, especially 
where the bulk of the poor are in the countryside. Low agricultural prices depress rural incomes, as well as the production and supply of food and agricultural products. The urban poor are however more politically powerful than the rural poor, not least as they are present in capital cities. An important contributor to the French Revolution of 1789 was the doubling of bread prices, and urban food protests have continued to pose a serious threat to governments.

Whereas in many developing countries farmers are discriminated against through price controls or restrictions on exports, which keep the price of their products artificially low, in many of the more advanced economies, and notably in the United States, European Union and Japan, certain groups of farmers have achieved an extraordinarily protected position. Tariff barriers and quotas which restrict imports, together with production, input subsidies, tax exemptions and other incentives benefit a small group of privileged farmers at the expense of consumers and taxpayers in the advanced economies. This fundamentally undermines the prospects of farmers in developing countries, who are unable to export the products that they are competitive in. It also makes the prices of these products more volatile on global markets, as only a small share of global production is traded so that the international markets become the residual, onto which excess production is dumped.

An added cause of instability is that the concentration of production in particular geographic areas of the United States and Europe increases the impact of weather related risks which exacerbates the instability in world food prices. Because farmers in many developing countries cannot export protected crops, they are compelled to concentrate their production in crops that are not produced in the advanced economies, and produce coffee, cocoa and other solely tropical agricultural commodities. This reduces diversification and leads to excessive specialisation in these commodities, depressing prices and raising the risks associated with monocultures. The levelling of the agricultural playing field, which has been a key objective of the Doha Development Round of Trade Negotiations, which was initiated by the World Trade Organization (WTO) in 2001, remains a key objective of development policy.

\subsection{Infrastructure}

Infrastructure is the basic physical and organisational structures and facilities required for the development of economies and societies. Infrastructure includes water and sanitation, electricity, transport (roads, railways and ports), irrigation and telecommunications. Infrastructure provides the material foundations for development. Investments in infrastructure tend to require very large and indivisible financial outlays and regular maintenance. These investments shape the evolution of cities, markets and economies for generations and lock in particular patterns of urbanisation and water and energy use. Prudent investment in energy and transport infrastructure can have a significant impact on environmental sustainability through ensuring lower emissions, higher efficiency and resilience to climate change. 
Investment in sewerage and sanitation, as well as recycling of water, similarly has a vital role to play in reducing water-use and pollution.

Public private partnerships can play a major role, especially in urban areas and in telecommunications and energy. Project finance and a range of other private investment structures are being used in a growing number of developing countries to encourage private investment in infrastructure. The outcomes have been decidedly mixed. In the United Kingdom, which has a reasonably sophisticated policy environment, public-private partnerships have been found by the National Audit office to provide poor value for money. In developing countries, following the bankruptcies of toll roads in Mexico and water utilities in Argentina, lessons have been learnt and developing countries now account for well over half of the private investments in infrastructure globally. Given infrastructure demands and the shortage of adequate government finance, there is a growing need for private power, telecommunications and other infrastructure investors to finance construction and operations. The mixed experience in recent decades points to the need for caution and the establishment of independent and powerful regulators to protect consumer interests from what can become natural monopolies or oligopolies.

\subsection{Legal Framework and Equity}

Laws serve to shape societies and, in particular, affect the nature of the relationships of citizens to each other and to their governments. Legal frameworks include the "systems of rules and regulations, the norms that infuse them, and the means of adjudicating and enforcing them". The rule of law has shaped development processes through the operation of laws, regulation and enforcement; enabled conditions and capacities necessary to development outcomes; and remained a core development end in itself. Therefore, the rule of law is of fundamental importance to development outcomes as it expresses and enables a society's conception of social and economic justice, and more specifically its attitudes to extreme poverty and deprivation. It also frames wealth, resource and power (re)distribution.

An effective legal and judicial system is an essential component for economic development, as it is for human development and basic civil liberties. Ensuring that decision making and justice are not determined by individual favours or corruption and that all citizens have equal access to the rule of law is vital to overcoming inequality and social exclusion. It is also required for the creation of transparent and well-functioning financial and other markets.

The relationship between the legal system and development is complex. In 1990, Douglas North and others pointed to a high positive correlation between the protection of property rights and long-term economic growth. Critics question whether the protection of property rights is a cause or a consequence of economic development. In this respect several studies have shown that access to legal information and the rule of law can enhance participation and promote socio-economic development by empowering the poor and marginalised, to claim rights, take advantage of economic 
and social opportunities and resist exploitation. The law and the courts can play an important role in defining identity and guaranteeing economic and social opportunities. The rule of law can improve access to service delivery by reallocating rights, privileges, duties and powers. Strengthening legal institutions that prevent violence and crimes that undermine the well-being of citizens promotes development.

Legal institutions that promote accountability and transparency, and curb corruption can similarly facilitate development. Consistent and fair regulation and dispute resolution facilitates the smooth operation of the market system, and reduces the opportunities for corruption, nepotism and rent seeking. The rule of law can also protect the environment and natural resources and promote sustainable development by enshrining workers, social and environmental rights in constitutions and legislation.

\section{The Future of Development}

Over the past 75 years ideas about the responsibility of development have shifted from the colonial and patronising view that poor countries were incapable of developing on their own and required the guidance and help of the rich colonial powers, to a view that each country has a primary responsibility over its own development aims and outcomes and that development cannot be imposed from outside. However, while both simple colonial and Marxist ideas of the interplay of advanced and developing countries are discredited, foreign powers and the international community can still exercise a profoundly positive or negative impact on development. This goes well beyond development aid as international trade, investment, security, environmental and other policies are typically more important. The quantity and quality of aid, the type of aid, as well as its predictability and alignment with national objectives nevertheless can play a vital role in contributing to development outcomes, particularly for low income countries and the least developed economies. Access to appropriate technologies and capacity building helps to lay the foundation for improved livelihoods. So although development is something which countries and citizens must do for themselves, the extent to which the international community is facilitating or frustrating development continues to influence and even at times dramatically shape development trajectories.

The extraordinary progress made in poverty reduction is evidence that development does happen. As is evident in Fig. 1, the number of people living under $\$ 1.25 \mathrm{a}$ day (at 2005 PPP) fell by almost 900 million between 1990 and 2011, even though the population of developing countries increased by over 2 billion over the same period. Much of this decline is attributable to the progress made in China, and to a lesser extent East Asia and India. The greatest development challenge remains in sub-Saharan Africa. We showed earlier that, particularly for the poorest countries, aid remains central to development efforts, but that aid also plays a vital role in other countries and in addressing public goods. 


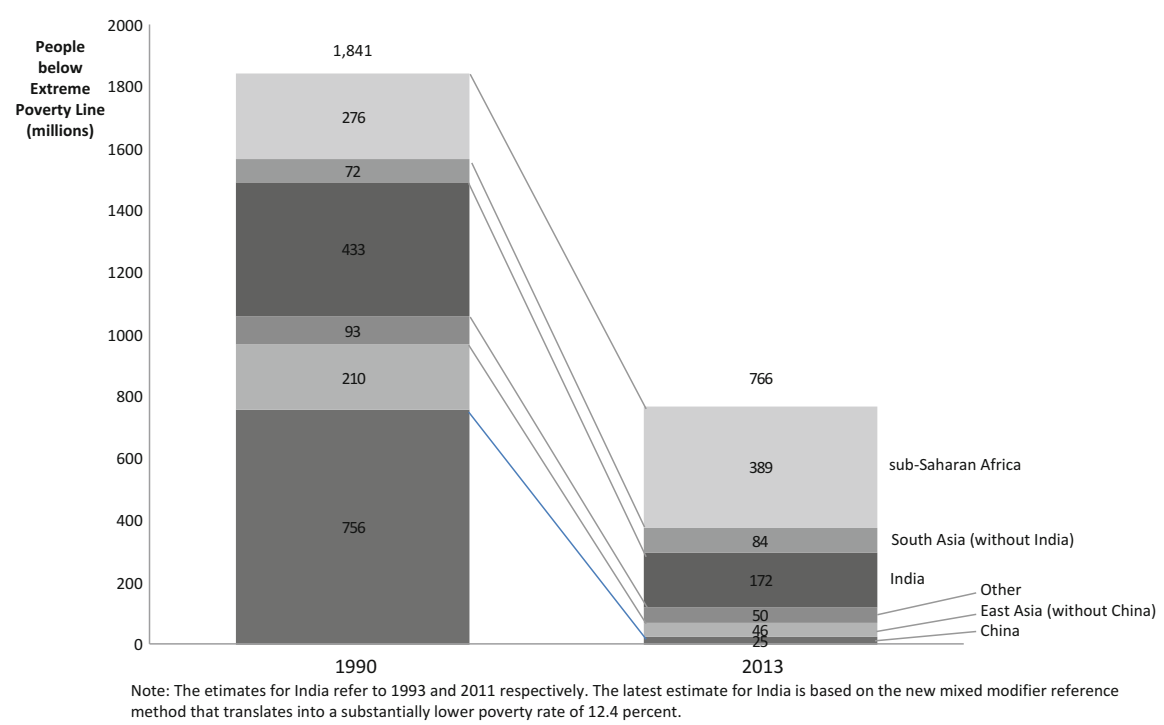

Fig. 1 People living on less than $\$ 1.90$ per day by region (1990-2013). Source: Ian Goldin, Development: A Very Short Introduction, Oxford University Press, 2018. (Reprinted with kind permission by C Oxford University Press 2018. All Rights Reserved.)

The latest poverty estimates for 2015 point to a further reduction in the number of people living below the $\$ 1.25$ poverty line, to around 835 million, the vast majority of whom continue to be located in South Asia (310 million) and sub-Saharan Africa (383 million). By 2030 the number of people living below the $\$ 1.25$ poverty line is projected to halve again (to around 411 million), with the vast majority of gains being made in South Asia where 286 million people are expected to escape extreme poverty.

In October 2015, the World Bank introduced a new "extreme poverty" line of $\$ 1.90$ per day at $2011 \mathrm{PPP}$. The new poverty line has implications for the number of people classified as poor and implies re-estimating historical poverty rates (Table 1). The latest headline figure for 2012 - the most recent year for which globally comparable data is available-suggests that close to 900 million people (or 12.8\% of the global population) live in extreme poverty. The majority are located in South Asia and sub-Saharan Africa, and to a lesser extent in South East Asia. Although global income poverty has been reduced dramatically (irrespective of the poverty line adopted), it important to remember that progress on many of the social indicators featured in the MDGs and SDGs has been slower.

It is now widely recognised that while governments must set the stage and invest in infrastructure, health, education and other public goods, the private sector is the engine of growth and job creation.

The coherence of aid and other policies is an important consideration. For example, supporting agricultural systems in developing countries requires not only 
Table 1 Total number and proportion of people below the $\$ 1.90$ poverty line (1990-2015)

\begin{tabular}{l|c|l|l|l|r|l|r|r}
\hline & \multicolumn{4}{|l|}{$\begin{array}{l}\text { Proportion below } \\
\$ 1.90\end{array}$} & \multicolumn{4}{l}{$\begin{array}{l}\text { Millions of people below } \\
\$ 1.90 \text { a day PPP 2011 }\end{array}$} \\
\hline & 1990 & 1999 & 2012 & 2015 & 1990 & 1999 & 2012 & 2015 \\
\hline East Asia and Pacific & 60.6 & 37.5 & 7.2 & 4.1 & 995.5 & 689.4 & 147.2 & 82.6 \\
\hline Europe and Central Asia & 1.9 & 7.8 & 2.1 & 1.7 & 8.8 & 36.8 & 10.1 & 4.4 \\
\hline $\begin{array}{l}\text { Latin America and the } \\
\text { Caribbean }\end{array}$ & 17.8 & 13.9 & 5.6 & 5.6 & 78.2 & 71.1 & 33.7 & 29.7 \\
\hline South Asia & & & & & & & & \\
\hline Sub-Saharan Africa & 50.6 & - & 18.8 & 13.5 & 574.6 & - & 309.2 & 231.3 \\
\hline World & 56.8 & 58.0 & 42.7 & 35.2 & 287.6 & 374.6 & 388.8 & 347.1 \\
\hline
\end{tabular}

Note: The Middle East and North Africa (MENA) is omitted as survey data coverage is too low The available evidence implies a poverty rate of $2.3 \%$ in the MENA region in 2012 and a poverty rate of $41.2 \%$ for South Asia in 1999

$2015=$ projection

investments in rural roads and irrigation, but also support for international research which will provide improved seeds, trade reform which allows access to crops, and actions which will stop the devastating impact of climate change on agricultural systems in many of the poorest countries. As noted earlier, the establishment of a level playing field for trade, and in particular the reduction of the agricultural subsidies and tariff and non-tariff barriers in rich countries that severely discriminates against agricultural development and increase food price instability, would provide a greater impetus for many developing countries than aid. Not all trade is good, and the prevention of small arms trade, toxic waste, slave and sex trafficking and other illicit trade should be curtailed and corruption dealt with decisively. The prevention of transfer pricing and of tax avoidance is important in building a sound revenue base which provides the means for governments to invest in infrastructure and health, education and other systems which provide the foundation for development.

The provision of global public goods, for example by improving the availability, price and effectiveness of vaccinations and drugs, especially against tropical diseases and the treatment of HIV/AIDS, is a similarly important contribution for the international community. The creation of an intellectual property regime that allows for affordable drugs and the encouragement of research on drugs and technologies that foster development, not least in agriculture, is another essential role for the international community.

The international community has a central role to play in the protection and restoration of the global commons, not least with respect to climate change and the environment. The establishment of global security and the implementation of agreements which seek to prevent genocide and facilitate the safe movement and fair treatment of migrants and refugees is another key responsibility of the international community. So too is the prevention of systemic risks. Poor people and poor countries are most vulnerable to all forms of risk, and so international efforts to reduce systemic 
risks which cascade over national borders is another area which requires the coming together of the international community.

Development is a national responsibility, but in an increasingly integrated world the international community has a greater responsibility to help manage the global commons as an increasing share of problems spill over national borders. All countries of the world share a collective responsibility for the planet, but the bigger and more advanced the country, the larger the share of this responsibility that it is capable of shouldering.

\subsection{Our Common Future}

As individuals get wealthier and escape poverty the choices they make increasingly impact on others. The tension between individual choice and collective outcomes is not new, with the study of the management of commons going back at least 500 years. Commons were shared lands, rivers or other natural resources over which citizens had access. In England, the rights of access became defined in common law. Many of these rights were removed in the enclosure movement which in the eighteen century converted most of the common lands into private property.

The tragedy of the commons refers to the overexploitation of common resources. Early examples include the overfishing of rivers, overgrazing of village fields or depletion of underground water. The management of the commons has led to the development of customary and more recently legally enforceable rules and regulations which limit the exploitation of shared resources. In recent decades however, the pressure on common resources, and in particular on the global commons, has grown with population and incomes. The global commons refers to the earth's shared natural resources, and includes the oceans, atmosphere, Polar Regions and outer space.

Development has meant that we are moving from a world of barely 500 million middle class consumers in the 1980s to a world of over 4 billion middle class consumers in the coming decade. This triumph of development is a cause for celebration. But it provides a source for growing alarm about our ability to cooperate and coexist in a sustainable manner on our beautiful planet. Greater individual choice is for many regarded as a key objective and outcome of development processes. Other outcomes include increasing life expectancy, higher incomes and rising consumption. Development has resulted in rapid population growth-two billion more people over the past 25 years with a further two billion plus expected by 2050. And globalisation has seen not only more connectivity but also an increase in the global flows of goods and services, with the sourcing of products and services from more distant places. The pressure on scarce resources has never been greater. Nor has the difficulty of managing them.

The result is a sharp rise in the challenge of managing the global commons, coupled with the rise of new collective challenges. Antibiotic resistance is one of 
these new challenges. While it is rational for individuals to take antibiotics to defeat infections, the more that people take antibiotics, the higher the risk of resistance. When combined with the growing use of antibiotics in animals, there is an escalating risk of antibiotic resistance, which would lead to rapid declines in the effectiveness of antibiotics, with dramatically negative consequences on these essential components of modern medicine. Other examples of the tension between our individual choice and collective outcomes include the consumption of tuna and other fish which are threatened with extinction, or our individual use of fossil fuel energy and the resulting collective implications for climate change.

As development raises income and consumption and increases connectivity, the spillover impact of individual actions grows. Many of these spillovers are positive. Evidence includes the close correlation between urbanisation and development. When people come together they can do things that they could never achieve on their own. However as incomes rise, so too do the often unintended negative spillover effects, with examples including obesity, diabetes, climate change, antibiotic resistance and biodiversity loss. Rising inequality and the erosion of social cohesion are also growing risks.

As Sen has explained, a key objective of development is freedom. Freedom to avoid want and starvation, to overcome insecurity and discrimination, and above all to be capable of achieving those things we have reason to value. But with this freedom comes new responsibilities. Our individual contribution to our shared outcomes and as guardians of future generations rises with our own development. If development is to be realised for all people, now and in the future, it is vital that we too develop as individuals. We need to ensure that we are free of the ignorance of how our actions interact with others. Development brings new responsibilities as well as freedoms.

\section{Bibliography}

Acemoglu, D., Johnson, S., \& Robinson, J. (2001). The colonial origins of comparative development: An empirical investigation. Colonialism and development. American Economic Review, 91(5), 1369-1401.

Acemoglu, D., Johnson, S., \& Robinson, J. (2002). Reversal of fortune, geography and institutions in the making of the modern world income distribution. Quarterly Journal of Economics, 117, 1231-1294.

Acemoglu, D., Naidu, S., Restrepo, P., \& Robinson, J. (2014). Democracy does cause growth (NBER working paper 200004). Cambridge, MA: National Bureau of Economic Research.

Adelman, I. (2006). Democracy and development. In D. A. Clark (Ed.), The elgar companion to development studies (pp. 105-111). Cheltenham: Edward Elgar.

Anup, S. (2010). Poverty facts and stats, global issues. Accessed October 10, 2015, from http:// www.globalissues.org/article/26/poverty-facts-and-stats\#src2

Baumol, W. (1986). Productivity growth, convergence and welfare: What the long-run data says. American Economic Review, 76, 1072-1085. 
Bundy, C. (1979). The rise and fall of the South African peasantry. Portsmouth, NH: Heinemann.

Collier, P. (2008). The bottom billion: Why the poorest countries are failing and what can be done about it. Resource endowments and the resource curse. New York: Oxford University Press.

Cruz, M., Foster, J., Quillin, B., \& Schellekens, P. (2015). Ending extreme poverty and sharing prosperity: Progress and policies. No 101740. Policy Research Notes (PRNs), The World Bank, p. 6 and table 1.

Diamond, J. (1997). Guns, germs and steel: A short history of everybody for the last 13,000 years. Geographical explanations of development. London: Vintage.

Easterly, W., \& Levine, R. (2003). Tropics, germs and crops: How endowments influence economic development. Journal of Monetary Economics, 50(1), 3-30.

Frankel, J. (2010). The natural resource curse. Cambridge, MA: National Bureau of Economic Research.

Frankel, J., \& Romer, D. (1999). Does trade cause growth? American Economics Review, 89(3), 379-399.

Goldin, I., \& Reinert, K. (2012). Globalization for development: Meeting new challenges. Globalization and development. New York: Oxford University Press.

Groningen Growth and Development Centre: Statistics on convergent and divergent growth across regions and countries, analysis of long-term growth (1870-2010) utilises available data on GDP per capita in 1990 US\$ from the Madison Project Database, http://www.ggdc.net/maddison/ maddison-project/home.htm (2013 version); the analysis of divergent growth patterns for the period 1960-2014 (including statistics for Ghana, South Korea and China) draws on available data on GDP per capita in 2005 US\$ from the World Bank, World Development Indicators (online). Accessed September 29, 2015, http://data.worldbank.org/

Hirschman, A. (1973). The changing tolerance for income inequality in the course of economic development. Inequality and development. Quarterly Journal of Economics, 87(4), 544-566.

Institute of Development Studies. (2010, September 12). Global poverty and the new bottom billion (Working paper, Sumner, A). Accessed October 10, 2015, from https://www.ids.ac.uk/files/ dmfile/GlobalPovertyDataPaper1.pdf

Kuznets, S. (1955). Economic growth and income inequality. American Economic Review, 45, $1-28$.

Li, H., \& Xu, Z. (2007). Economic convergence in seven Asian economies. Review of Development Economics, 11(3), 531-549.

Page, J. (MIT, 1994). The East Asian miracle: Four lessons for development policy. In S. Fischer \& J. Rotemberg (Eds.), NBER macroeconomics manual 1994 (pp. 219-282). Cambridge, MA. Accessed October 1, 2015, from http://www.nber.org/chapters/c11011.pdf

Parente, S., \& Prescott, E. (1993). Changes in the wealth of nations. Quarterly Review, 17(2), 3-16.

Rodrik, D., Subramanian, A., \& Trebbi, F. (2004). Institutions rule: The primacy of institutions over integration and geography in economic development. Institutions and governance. Journal of Economic Growth, 9(2), 131-165.

Sachs, J. (1989). Developing country debt and the world economy. Chicago: University of Chicago Press.

Sachs, J., \& Warner, A. (1995). Economic convergence and economic policies. Relationship between trade and development. Cambridge, MA: National Bureau of Economic Research.

Sen, A. (1981). Poverty and famines: An essay on entitlement and deprivation. The role of power and other factors. Oxford: Clarendon Press.

Singh, A. (1995, February 8). "Close" vs. "Strategic" integration with the world economy and the "Market Friendly Approach to Development" vs. "An Industrial Policy" (MPRA paper no. 53562). Accessed October 1, 2015, from https://mpra.ub.uni-muenchen.de/53562/1/ MPRA_paper_53562.pdf

Solow, M. R. (1956, February). Uneven development and convergence. A contribution to the theory of economic growth. The Quarterly Journal of Economics, 70(1), 65-94. 
World Bank, Development Research Group. PovcalNet: The online tool for poverty measurement, poverty and inequality. Accessed October 18, 2015, from http://iresearch.worldbank.org/ PovcalNet/index.htm?1

World Health Organization. (2015, September 17). WHO/UNICEF report: Malaria MDG target achieved amid sharp drop in cases and mortality, but 3 billion people remain at risk. Joint WHO/UNICEF News Release. Accessed October 3, 2015, from http://www.who.int/ mediacentre/news/releases/2015/malaria-mdg-target/en/

Open Access This chapter is licensed under the terms of the Creative Commons Attribution 4.0 International License (http://creativecommons.org/licenses/by/4.0/), which permits use, sharing, adaptation, distribution and reproduction in any medium or format, as long as you give appropriate credit to the original author(s) and the source, provide a link to the Creative Commons licence and indicate if changes were made.

The images or other third party material in this chapter are included in the chapter's Creative Commons licence, unless indicated otherwise in a credit line to the material. If material is not included in the chapter's Creative Commons licence and your intended use is not permitted by statutory regulation or exceeds the permitted use, you will need to obtain permission directly from the copyright holder.

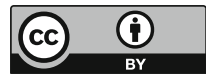

